Sains Malaysiana 50(3)(2021): 839-847

http://dx.doi.org/10.17576/jsm-2021-5003-24

\title{
Influence of the Oil Phase on the Wound Healing Activity of Sea Cucumber Extract- Based Cream Formulations
}

(Pengaruh Fasa Minyak pada Aktiviti Penyembuhan Luka oleh Formulasi Krim yang Berasaskan Ekstrak Timun Laut)

\author{
Thiviya Sunmugam, Hanisah AzHari, Ng Shiow-Fern \& FAZRen AZMI*
}

\begin{abstract}
Sea cucumbers are attractive marine natural sources as they are enriched with functional biomaterials that can contribute in accelerating wound healing. The present study was carried out to prepare cream formulations comprising extract of sea cucumber with different type of oil phase, namely F1 (olive oil), F2 (tea tree oil) and F3 (lemongrass oil) to assess the influence of the oil on the physicochemical properties and the wound healing efficacy of the creams. The formulated creams showed satisfactory physicochemical characteristics such as homogeneity, spreadability, rheology, $\mathrm{pH}$, and showed no evidence of phase separation even when the creams were kept at extreme conditions. The ex vivo release profile of sea cucumber extract from the formulated creams was determined by using a Franz diffusion cells. $F 3$ demonstrated a constant and yield the highest release percentage of sea cucumber extract, followed by F2 and F1. Topical application of the formulated creams on the excision wound in rats showed a significant wound healing efficacy compared to the control group. Among the creams formulation, F1 demonstrated a significantly higher rate of wound closure compared to F2, F3, and positive control. The wound healing efficacy of the formulated creams were not dependent on the ability of the oils in promoting skin permeation for the release of sea cucumber extract. This study depicted that lemongrass oil acted as a good skin permeation enhancer for the release of sea cucumber extract while olive oil worked in a more synergistic manner with sea cucumber extract in promoting wound healing.
\end{abstract}

Keywords: Oil phase; permeation enhancer; sea cucumber extract; wound healing

\section{ABSTRAK}

Timun laut adalah sumber semula jadi laut yang menarik kerana ia diperkaya dengan biobahan yang mampu berfungsi untuk merangsang proses penyembuhan luka. Kajian yang dijalankan merangkumi formulasi krim yang mengandungi ekstrak timun laut dengan pelbagai jenis fasa minyak, iaitu FI (minyak zaitun), F2 (minyak pohon teh) dan F3 (minyak serai) untuk mengkaji pengaruh jenis minyak pada sifat fizikokimia dan keberkesanan penyembuhan luka. Kesemua krim yang diformulasikan menunjukkan ciri-ciri fizikokimia yang memuaskan seperti kehomogenan, daya sebaran, reologi, pH dan tidak menunjukkan bukti pemisahan fasa walaupun krim disimpan dalam keadaan suhu yang melampau. Profil pelepasan ex vivo ekstrak timun laut daripada krim yang dirumuskan telah dinilai menggunakan sel resapan Franz. F3 menunjukkan kadar pelepasan ekstrak timun laut yang sekata dan perstusan tertinggi, diikuti oleh F2 dan F1. Aplikasi kesemua krim secara topikal pada pemotongan luka menunjukkan keberkesanan penyembuhan luka yang signifikan berbanding kumpulan kawalan. Di antara krim yang dirumus, F1 menunjukkan kadar penyembuhan luka yang lebih tinggi berbanding F2, F3 dan kawalan positif. Keberkesanan penyembuhan luka daripada krim yang dirumuskan tidak bergantung pada kemampuan minyak dalam mempromosikan permeasi kulit untuk pembebasan ekstrak timun laut. Kajian ini merumuskan bahawa minyak serai bertindak sebagai agen permeasi kulit yang berkesan untuk pembebasan ekstrak timun laut sementara minyak zaitun berfungsi dengan cara yang lebih sinergistik dengan ekstrak timun laut dalam merangsang penyembuhan luka.

Kata kunci: Agen permeasi; ekstrak timun laut; fasa minyak; penyembuhan luka

\section{INTRODUCTION}

Wound can be defined as an interruption to the normal cellular, functional, and anatomical structure of a skin. Wounding, irrespective of the cause leads to the opening and breaking of skin, which eventually damages the tissue. Normal wound healing is a complex process, which involves a coordination of various events such as coagulation, inflammatory response, migration and proliferation of connective tissues (Rivera \& Spencer 2007). The wound healing process is completed when the 
disrupted surface is firmly knitted by collagen as an attempt to restore the morphological and functional integrity of skin (Martin \& Nunan 2015). The healing process can be facilitated by correct approach in treating wounds. The basic principle of optimal wound healing is to minimize tissue damage and provides adequate tissue perfusion and oxygenation, proper nutrition, and moist wound healing environment to restore the anatomical continuity and function of the affected part.

In the recent decades, sea cucumbers, a marine invertebrate commonly known as 'gamat' in Malaysia have gained interest as wound healing agents. The effectiveness of sea cucumbers in wound healing can be attributed to the presence of its active substances such as fatty acids, glycoprotein, phenolic peptides and triterpenes that play a major role in inducing tissue repairs and regenerations (Oh et al. 2017). Moreover, sea cucumbers extracts possess several biological activities such as anti-inflammatory (Himaya et al. 2010), antibacterial (Omran \& Allam 2013), antioxidant (Mamelona et al. 2007) and anticoagulation (Cai et al. 2018) which imperatively facilitate the wound healing process. Due to its pharmacological benefits, sea cucumbers have been explored for medical use, particularly in dermatological formula for wound management.

In the present study, sea cucumber extract was formulated into cream by proportionately mixing with different types of natural oil phase; olive oils, tea tree oil and lemongrass oil. Oil phase is often used as delivery vehicles to enhance the stability and therapeutic efficacy of the active substances in cream formulation. Moreover, the selected oil phases are consisted of constituents such as terpenes and oxygenated compounds that have been shown to be effective as skin permeation enhancer (Herman \& Herman 2015). The selected oils are also considered as GRAS (generally regarded as safe) for medicinal use and have limited irritation when applied on skin (Aqil et al. 2007). The physicochemical properties including stability, spreadability and rheological properties of the formulated creams were investigated. The effects of different type of oil phase on skin permeation of sea cucumber extract were evaluated using Franz diffusion cells fitted with excised rat skin. The wound healing efficacy of the formulated creams were assessed on a fullthickness excision wound model by using rats. Overall, this study elucidated the influence of different type of oil phase in inducing the release of sea cucumber extract from the cream formulations and its ability to promote wound healing.

\section{MATERIALS AND METHODS MATERIALS}

Water-soluble sea cucumber (derived from Sticophus horrens) extract was kindly provided by Healwell Pharmaceuticals Sdn Bhd (Malaysia). Olive oil (R\&M chemicals, UK), tea tree oil (Wipro Unza, Malaysia) and lemongrass oil (Maxwell Pharma, Malaysia) were used as oil phases. Commercial sea cucumber-based cream was purchased from Gamat Asli Enterprise (Malaysia). Beeswax and Span 80 from Sigma-Aldrich (USA) were purchased from Sigma-Aldrich (USA). Tween 80 was supplied by R\&M chemicals (UK). Methanol (HPLC analytical grade) was obtained from Fisher Scientific (UK).

\section{FORMULATION OF CREAMS (W/O EMULSION)}

The sea cucumber-based creams were formulated and prepared based on the following summarized method. The aqueous phase was consisted of sea cucumber extract. The oil phase was composed of natural oil, beeswax, Tween 80 and Span 80 . Three cream formulations were prepared with the only difference between them was the type of natural oil used while other ingredients remained the same as presented in Table 1. Briefly, the oil phase was heated up to $70{ }^{\circ} \mathrm{C}$. Simultaneously, the aqueous phase containing sea cucumber extract was heated to the same temperature. Then, the aqueous phase was added to the oil phase drop by drop with constant stirring. The mixture was stirred slowly and continuously until a uniform cream was formed at room temperature $\left(25^{\circ} \mathrm{C}\right)$. The resulting cream was cooled at room temperature and stored in an amber jar prior to further evaluations.

TABLE 1. Composition of sea cucumber extract-based cream formulations with different type of oil phases

\begin{tabular}{lccc}
\hline & \multicolumn{3}{c}{ Cream formulations } \\
\cline { 2 - 4 } Composition & Formulation $1(\mathrm{~F} 1)$ & Formulation 2 (F2) & Formulation 3 (F3) \\
\hline Water-soluble extract of sea & 15 & 15 & 15 \\
cucumber $(\% \mathrm{w} / \mathrm{w})$ & 5 & - & - \\
Olive oil $(\% \mathrm{w} / \mathrm{w})$ & - & 5 & 5 \\
Tea tree oil $(\% \mathrm{w} / \mathrm{w})$ & - & - & 5 \\
Lemongrass oil $(\% \mathrm{w} / \mathrm{v})$ & 5 & 5 & 1 \\
Beeswax $(\% \mathrm{w} / \mathrm{w})$ & 1 & 1 & 4 \\
Tween $80(\% \mathrm{w} / \mathrm{w})$ & 4 & 4 & $\mathrm{qs}$ \\
Span $80(\% \mathrm{w} / \mathrm{w})$ & $\mathrm{qs}$ & $\mathrm{qs}$ & \\
Water, $\mathrm{qs}, 100(\mathrm{~mL})$ & & & \\
\end{tabular}




\section{PHYSICAL APPEARANCE}

The formulated creams were visually observed for their appearance, colour and texture.

\section{DETERMINATION OF PH}

$\mathrm{pH}$ paper was used to determine the $\mathrm{pH}$ of the prepared creams. The $\mathrm{pH}$ paper was immersed about $0.5 \mathrm{~cm}$ into the cream. A change in colour is an indicative of the acidity or alkalinity of the cream. The $\mathrm{pH}$ paper allows a distinct colour changes at $\mathrm{pH}$ 1-14.

\section{STABILITY TESTING}

The creams were tested for stability under freezing and overheating conditions by exposing it to a series of freeze-thaw cycle testing based on the reported method with slight modification (Zhang et al. 2019). Initially, the samples were kept at room temperature for $24 \mathrm{~h}$. Then, they were placed in the refrigerator $\left(2-7^{\circ} \mathrm{C}\right)$ for another $24 \mathrm{~h}$. The creams were then thawed again at room temperature for $24 \mathrm{~h}$. Next, the creams were placed at a higher temperature in the oven $\left(41^{\circ} \mathrm{C}\right)$ for the next $24 \mathrm{~h}$. Finally, the creams were thawed again at room temperature for $24 \mathrm{~h}$. The physical characteristics of the creams such as colour, liquefaction and phase separation were observed after the storage cycles.

\section{SPREADABILITY}

Approximately $3 \mathrm{~g}$ of cream was applied in between two glass slides. A $200 \mathrm{~g}$ weight was placed upon the upper slide so that the cream between the two slides was pressed uniformly to form a thin layer. The bottom glass slide was restrained to reduce sliding. The upper glass slide was pulled for $10 \mathrm{~s}$ and the distance moved by the glass slides was measured. The procedure was carried out in triplicate and the average of three readings was determined. Spreadability (S) was calculated by using the following formula:

$$
\mathrm{S}=\mathrm{M} \cdot \mathrm{L} / \mathrm{T}
$$

where $\mathrm{M}$ is the weight ( $\mathrm{g}$ ) tied on upper slide; $\mathrm{L}$ is the length $(\mathrm{cm})$ moved by glass slide, and $\mathrm{T}$ is the time (s) taken to separate the slides from each other.

\section{RHEOLOGICAL PROPERTIES (VISCOSITY)}

Viscosity of the creams was determined by using a Bohlin Gemini Rheometer (UK). It was carried out in room temperature following the continuous shear procedure. The parameters of the experiment include: minimum shear rate: $0.5 \mathrm{~s}^{-1}$, maximum shear rate: $100 \mathrm{~s}^{-1}$, descending curve time: $120 \mathrm{~s}$, ascending curve time: $120 \mathrm{~s}$, and temperature: $25^{\circ} \mathrm{C}$. The procedures were carried out in triplicate and the average viscosity at the maximum shear rate was determined.

\section{ex vivo SEA CUCUMBER EXTRACT RELEASE STUDIES}

Ex vivo release studies were carried out by using Franz diffusion cell (Permegear Inc., USA) with effective diffusional surface area of $1.13 \mathrm{~cm}^{2}$. Initially, the dorsal hair of the rat was removed using an electric razor. The skin then was surgically removed and cut into smaller pieces with a size dimension of $2 \mathrm{~cm}^{2}$. The rat skin was soaked in distilled water prior to use. Then, the rat skin was sandwiched between the donor and receptor compartment of the diffusion cell. A clamp was used to keep both of the donor and receptor compartment intact. The receptor compartment was filled with $3.5 \mathrm{~mL}$ of distilled water which was maintained at $37^{\circ} \mathrm{C}$ by placing it into a water bath. The donor compartment of the cell was filled with $1 \mathrm{~g}$ of cream containing the sea cucumber extract. $0.5 \mathrm{~mL}$ sample was withdrawn after $1,2,4,6$, and $8 \mathrm{~h}$. The receptor was replaced with an equal volume of distilled water to maintain the sink conditions. The collected samples were then analysed by using an Agilent 1200 high performance liquid chromatography (HPLC) system. The column used was a reversed-phased column C18 (4.6 × $250 \mathrm{~mm}, 5 \mu \mathrm{m}$; XBridge, Waters, Dublin, Ireland). A gradient elution was accomplished with a mobile phase of methanol: water (50\%:50\%), pumped at a flow rate of $1.0 \mathrm{~mL} / \mathrm{min}$ at a wavelength of $215 \mathrm{~nm}$ Standard curve of sea cucumber extract ranging from $5 \%(\mathrm{v} / \mathrm{v})$ to $25 \%(\mathrm{v} / \mathrm{v})$ yielded linear responses over the concentration range with detection at $215 \mathrm{~nm}$. The Franz cell analysis of sea cucumber extract release from the cream formulations was performed in triplicate, and the mean cumulative percentage releases from three batches were calculated.

\section{in vivo EVALUATION ON RAT EXCISION WOUND MODEL}

The animal studies were conducted in compliance with institutional protocol with the UKMAEC approval number (FF/2017/FAZREN/27-SEPT./865-SEPT.2017FEB.2018). Total of five healthy male Albino Wistar rats weighing between 250-300 g were obtained from Laboratory Animal Resource Unit, Universiti Kebangsaan Malaysia (UKM). The rats were housed and maintained in a controlled environment condition (12-h light/12-h dark cycle, $22 \pm 3{ }^{\circ} \mathrm{C}$ temperature). They were fed with rat pellets and clean water. The animals were acclimatized under standard laboratory condition before the experiment. Those five rats were housed individually. They were 
divided into negative control, positive control, formulation 1, formulation 2 and formulation 3. Prior to wound induction the rats were weighed to determine the dosage of anaesthetic to be given. The rats were anesthetized with Ketamine + Xylazine + Zoletil (KTX) intraperitoneally.

The dosage given was $0.2 \mathrm{~mL}$ per $100 \mathrm{~g}$. The rats were shaved by using an electric razor (BaoRun Professional Animal Clippers) to remove the hairs on the back part (dorsal areas $\sim 5 \mathrm{~cm}^{2}$ ) of the body. Six full thickness excision wounds $(n=6)$ were induced in each rat of the five tested groups. The wounds were induced by using a sterile $6 \mathrm{~mm}$ biopsy punch (Kai Medical, Japan). Any excessive bleeding was cleaned by using an alcohol swab.

The wounds were applied with approximately 0.1 $\mathrm{g}$ of creams once daily for 14 days according to their respective groups. The negative control was left untreated. The wound area was photographed periodically, starting from day 0 . Wound measurements were taken on day 4 , 8 and 14. The diameters of the wound were measured to calculate the percentage of wound contraction. The rate of healing was calculated and expressed as percentage contraction:

$\%$ Wound contraction on day $\mathrm{N}=[$ (area on day 0 - area on day $\mathrm{N}$ )/area on day 0$] \times 100$

\section{STATISTICAL ANALYSIS}

All data were analysed using GraphPad Prism 5. The data were presented as mean \pm standard deviation. The statistical analysis was determined using one-way ANOVA analysis with Tukey's post hoc test. P value $<0.05$ was indicated to be statistically significant for the tested groups.

\section{RESULTS AND DISCUSSION}

\section{PHYSICOCHEMICAL CHARACTERISATIONS OF THE FORMULATED CREAMS}

Sea cucumber extract obtained in water-soluble form was made into water-in-oil (W/O) creams by proportionately mixing with different types of natural oils (Table 1). Other ingredients and fabrication parameters were kept constant; therefore, the difference of the formulated creams was solely on the type of oils used. The water-in-oil (W/O) cream formulation was chosen over oil-in-water $(\mathrm{W} / \mathrm{O})$ as it has a greater moisturizing effect and emulsification of hydrophilic active ingredient, i.e., sea-cucumber extract.

The formulated creams were characterized in terms of its physical appearance, $\mathrm{pH}$, homogeneity, spreadability, and viscosity. The freshly prepared emulsions were yellowish-white in colour for F1 and solid white for F2 and F3. All of the formulated creams exhibited a smooth and homogenous appearance. The $\mathrm{pH}$ of the formulated creams was within the range of 5 to 6 , which is in parallel with the typical $\mathrm{pH}$ (4.5 to 6.0) range of human skin (Table 2) (Chikakane \& Takahashi 1995; Matousek et al. 2003). An acidic skin $\mathrm{pH}$ is important for controlling the presence of resident skin microflora and providing optimal condition for physiological process, such as stratum corneum (SC) homeostasis (Lambers et al. 2006). F3 showed the highest spreadability value followed by F2 and F1. The high values of spreadibiltiy demonstrated that the formulation is readily and evenly spread on the application surface within the tested period of time. Thus, the spreadabiltiy evaluation is important to provide an indicator on how well the cream formulations can be evenly spread on the skin.

Viscosity values of the formulated creams are shown in Table 2. It is generally accepted that the viscosity of emulsion plays a vital role on its flow behavior. Thereby it is assumed that the lower the viscosity of the semisolid formulation, the greater its spreadability (Kwak et al. 2015). This correlation was observed in this study in which F3 that possess the highest degree of spreadability has a lowest viscosity value compared to F1 and F2. All formulated creams exhibited shear-thinning behaviour as shown in Figure 1, which is a desirable attribute for topical products. This means that the viscosity is not a constant value, in which the viscosity changes as the shear rate changes.

The creams stability was assessed by exposing them to various temperatures for a specific period of time. The samples were observed for changes in colour, $\mathrm{pH}$, liquefaction, and phase separation. There were no changes observed in the formulated creams based on the tested parameters even at the highest temperature $\left(41^{\circ} \mathrm{C}\right)$ and the longest period of storage times (up to $96 \mathrm{~h}$ of observation). The findings showed that all of the formulated creams were stable at all of the tested storage conditions, including under extreme and rapid temperature changes.

TABLE 2. Physicochemical characterisations of the freshly prepared creams

\begin{tabular}{cccc}
\hline Results/ Formulations & F1 & F2 & F3 \\
\hline $\mathrm{pH}$ & $6 \pm 0$ & $5 \pm 0$ & $5.3 \pm 0.58$ \\
& & & $18 \pm 0$ \\
Spreadability $(\mathrm{g} . \mathrm{cm} / \mathrm{sec})$ & $6.67 \pm 3.06$ & $14 \pm 2.00$ & $1.97 \pm 0.20$ \\
Viscosity (Pas) & $22.55 \pm 1.95$ & $2.46 \pm 0.23$ & \\
\hline
\end{tabular}


ex vivo RELEASE PROFILE OF SEA CUCUMBER EXTRACT

The ex vivo release profile of sea cucumber extract from various cream formulations containing different types of oils were determined by using Franz diffusion cell analysis as illustrated in Figure 2. The release and transport of sea cucumber extract through full-thickness rat skin is useful to gain insight on how much of the active ingredient is available for absorption. It has been demonstrated that there was insignificant difference in terms of variation on the permeation rates of the studied drugs between rat skin and human skin (Takeuchi et al. 2011). Thus, this study provides an insight on the influence of different type of natural oils in inducing the absorption of active sea cucumber extract through human skin. The results indicated that the cream formulation containing lemongrass oil has the highest percentage of sea cucumber extract release followed by tea tree oil and olive oil. Lemongrass oil showed efficient diffusion rate as it is rich with oxygen containing hydrophilic terpenes, such as farnesol, geraniol, and citral which can greatly enhance penetration of the tested hydrophilic compound; water-soluble sea cucumber extract. Similarly, there was insignificant difference $(\mathrm{p}>$ 0.05 ) between the release rate of sea cucumber extract between cream formulation containing lemongrass oil and tea tree oil. This is because tea tree oil possesses large proportion of terpenes that contain hydroxyl group, particularly terpinen-4-ol which may contribute to the satisfactory release profile of sea cucumber extract (Carson et al. 2006). However, F1 that contains olive oil exhibited a poor release rate of sea cucumber extract and only lasted for $4 \mathrm{~h}$. Olive oil contains a high concentration of oleic acid, which possess a long hydrocarbon chain that may result in less effective in absorbing hydrophilic sea cucumber extract (Viljoen et al. 2015). These findings suggested that oils that bearing terpenes with polar functional group was more effective in enhancing the permeation of hydrophilic compound than oils with long hydrocarbon-based terpenes. It is believed that the polar functional group allow them to interact with the amide group of the stratum corneum ceramides in higher affinity compared to the terpenes with a carbonyl group (Chen et al. 2016; Pham et al. 2016). This may result in the disruption of the barrier that is made up from the hydrogen bonding between the lipidic bilayers, thus increasing the diffusion coefficient of water-soluble cucumber extract through the stratum corneum. These findings were in good agreement with previous studies where fatty acids-enriched natural oils, such as olive oil was more compatible in increasing the permeation of lipophilic drugs, while monoterpenoids-enriched essential oils (such as tea tree and lemongrass oil) increase the stratum corneum permeability to hydrophilic drugs (Nanayakkara et al. 2005; Narishetty \& Panchagnula 2004).

\section{WOUND HEALING ACTIVITY}

The results indicated that all of the newly formulated sea cucumber extract-based creams containing different types of oil phases (F1, F2 and F3) significantly (P < 0.001 ) enhanced the wound contraction compared to the negative control group (Figure 3). The ability of F2 and F3 to induce wound contraction was comparable ( $\mathrm{P}>$ 0.05 ) to the commercially available sea cucumber-based cream product (positive control). F1 however exhibited a superior wound healing activity over the positive control. This result was in parallel with the visual proof of wound healing pattern that was obtained by taking macroscopic photographs periodically (Figure 4). As observed from the results, the F1 treated wounds demonstrated increased rate of wound healing compared to the other tested groups, including the positive control. It was clearly visualised that the F1 treated wound was completely healed at day 14. This data was in good agreement with the planimetric results, where the wound closure percentage of $\mathrm{F} 1$ was nearly $100 \%$ (Table 3 ). This means that the F1-treated wounds required a maximum of 14 days for complete re-epithelization compared to other formulations, which may require extended days for a maximal wound closure. Overall data suggested that the combination of sea cucumber extract and olive oil (F1) demonstrated an enhanced wound healing activity on excised wounds created on the rat's dorsal backs, followed by F2 and F3.

However, the results from wound healing efficacy studies seem to be contradicted to the ex vivo release study of sea cucumber extract. Interestingly, F3 which contain lemongrass oil as the oil phase was found to be the most effective cream formulation in inducing an efficient and constant release of sea cucumber extract, exhibited the least efficacy in promoting wound closure as observed in the in vivo studies. Thus, these data showed that the ex vivo release performance of the formulated creams was not correlated to their wound healing efficacy in animal model. This is maybe due to the fact that the structural integrity of stratum corneum was impaired during wound injury which leads to the permeation of respective natural oils and sea cucumber extract to the wounded area. Therefore, the synergy effects between the selected oils and sea cucumber extract have a more profound influence in the healing process compared to the role of oil phase as permeation enhancer in excision wound model. Olive oil contains large amounts of antioxidants, such as $\alpha$-tocopherol (one of the most important natural antioxidant) compared to lemongrass and tea tree oil (Gouvinhas et al. 2017). Antioxidants are useful to suppress oxidative stress and thereby accelerate wound healing (Pessoa et al. 2016; Süntar et al. 2012). Olive oil is also composed of high percentage of monosaturated oleic acid, which was proven 
to exhibit anti-inflammatory effects which may contribute to its wound healing efficacy by increasing the rate of blood flow (Donato-Trancoso et al. 2016).

TABLE 3. Percentage of wound closure at different days' interval (mean $\pm \mathrm{SD}, \mathrm{n}=6)$

\begin{tabular}{cccccc}
\hline \multirow{2}{*}{ Day } & \multicolumn{5}{c}{ Percentage (\%) of wound contraction on excision wounds } \\
& Negative control & Positive control & F1 & F2 & F3 \\
\hline 4 & $0 \pm 0$ & $15.27 \pm 16.73$ & $37.96 \pm 22.27$ & $31.42 \pm 21.35$ & $33.79 \pm 20.59$ \\
8 & $30.54 \pm 0$ & $60.18 \pm 19.93$ & $84.26 \pm 7.17$ & $76.39 \pm 12.27$ & $59.14 \pm 19.09$ \\
14 & $74.02 \pm 27.59$ & $87.96 \pm 7.17$ & $96.76 \pm 4.09$ & $90.25 \pm 8.93$ & $83.79 \pm 16.05$ \\
\hline
\end{tabular}

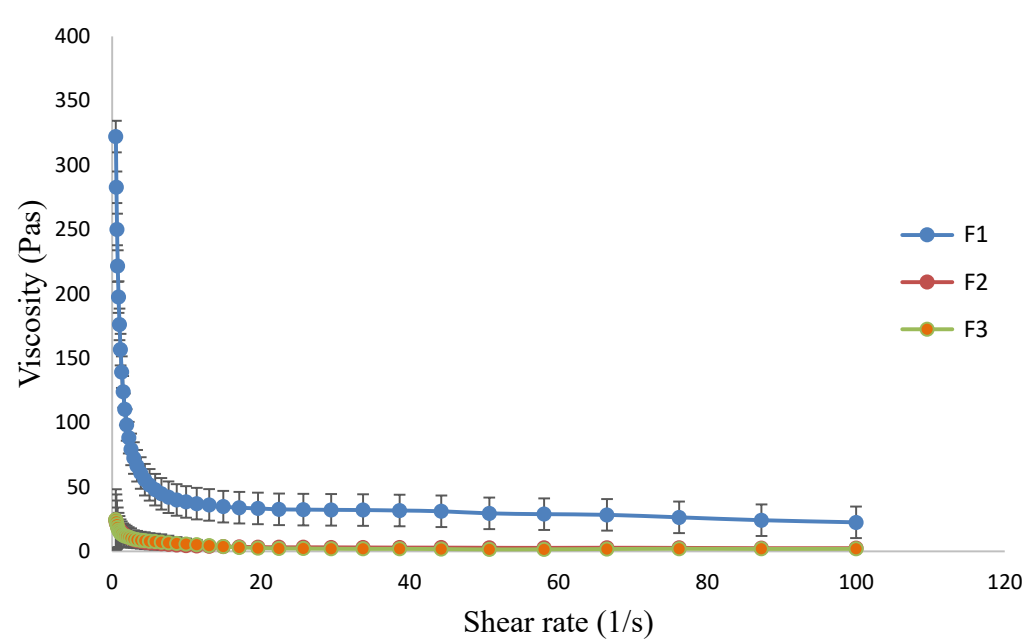

FIGURE 1. Shear-rate-dependent viscosity curves of the formulated creams at $25^{\circ} \mathrm{C}$

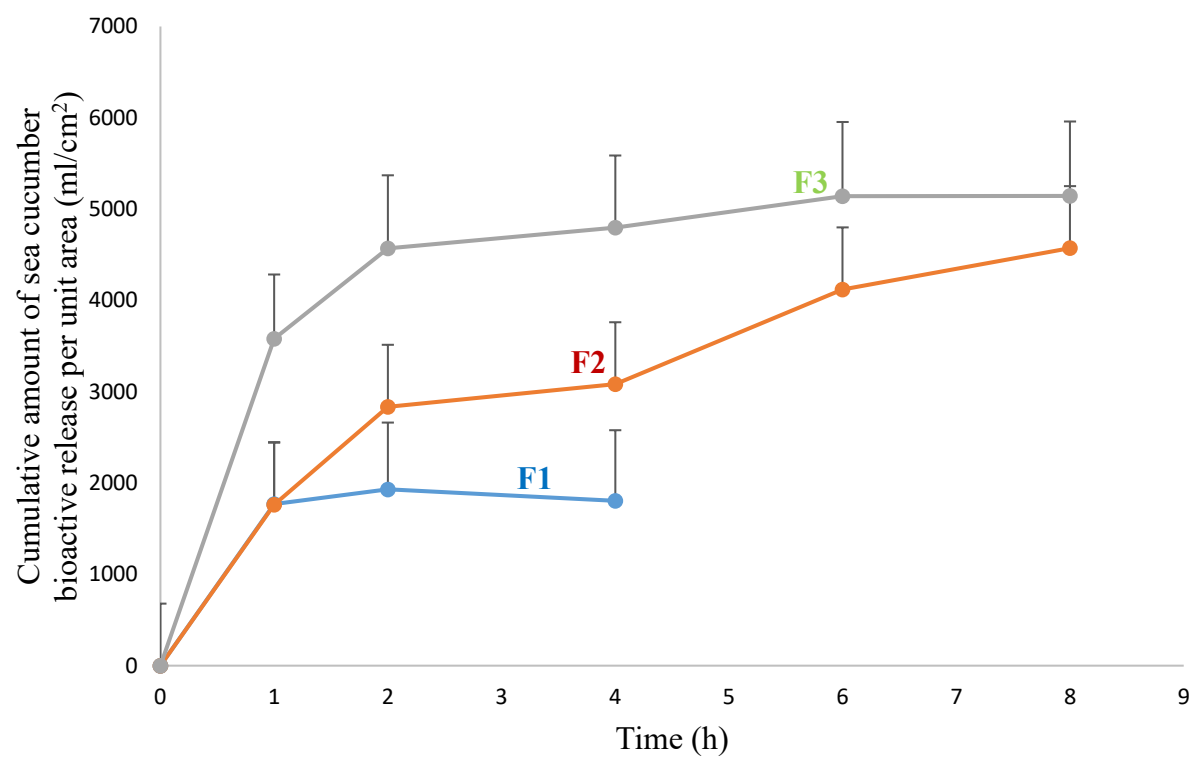

FIGURE 2. Cumulative amount of sea cucumber extract release from the formulated creams. $\mathrm{n}=3$, data points are presented as mean $\pm \mathrm{SD}$ 


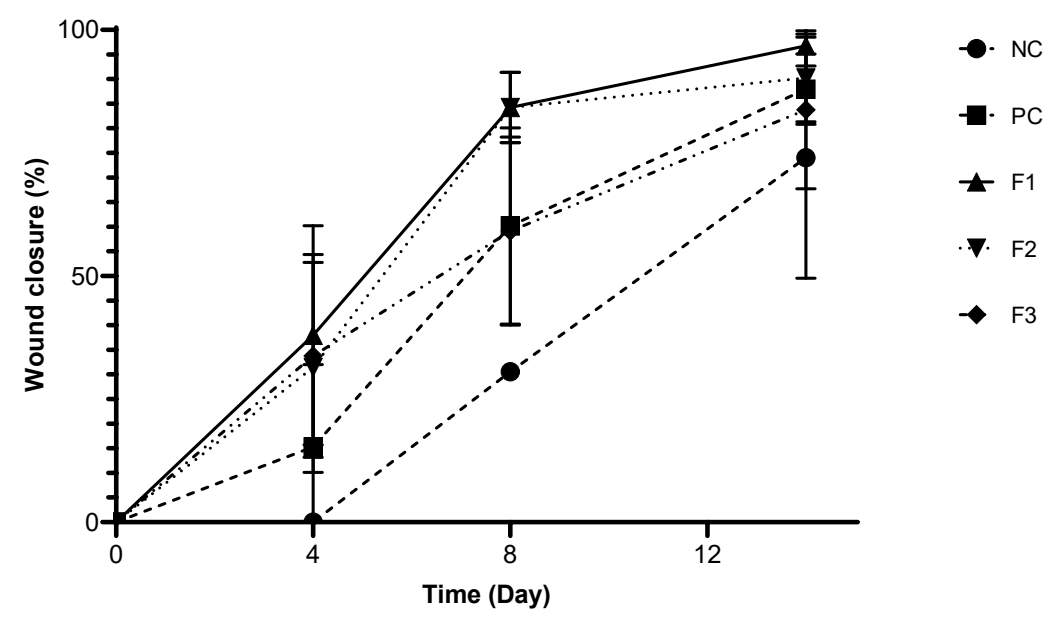

FIGURE 3. The effects of the formulated creams on wound healing progress towards the incision wounds. Data presented as mean $\pm \mathrm{SD}, \mathrm{n}=6, * * \mathrm{P}<0.01$ and $* * * \mathrm{P}<0.001$, the tested groups were compared with the control groups)

NC
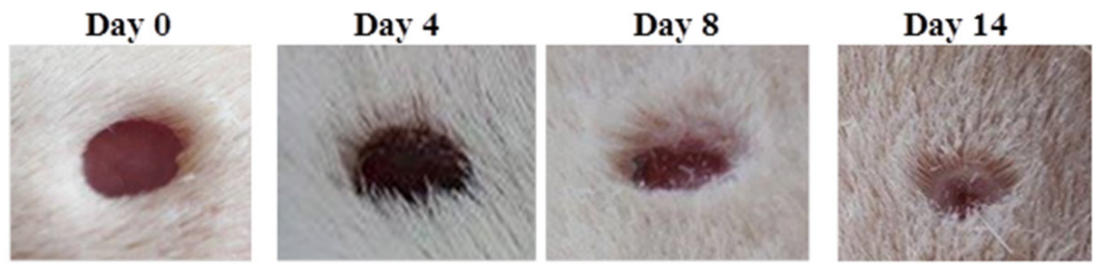

PC
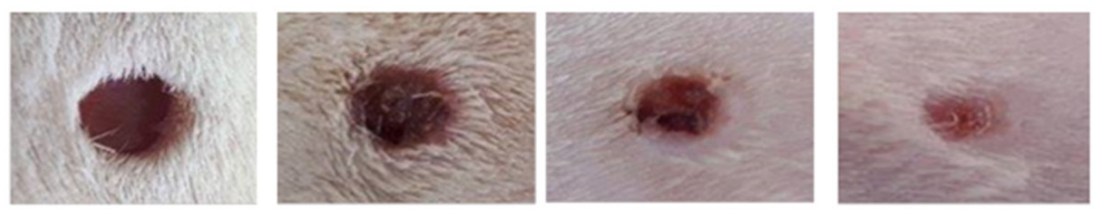

F1
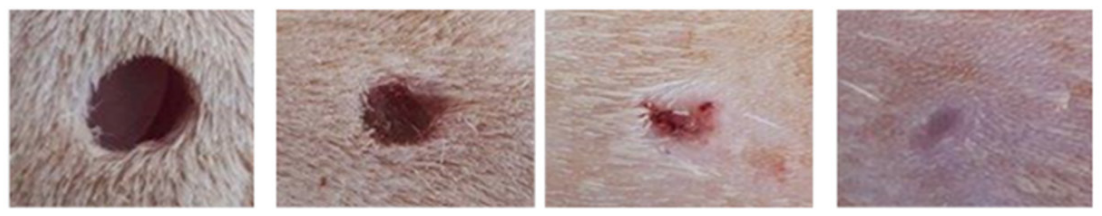

F2
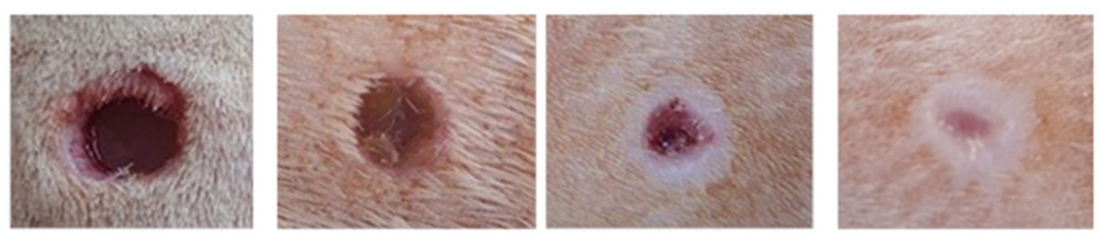

F3
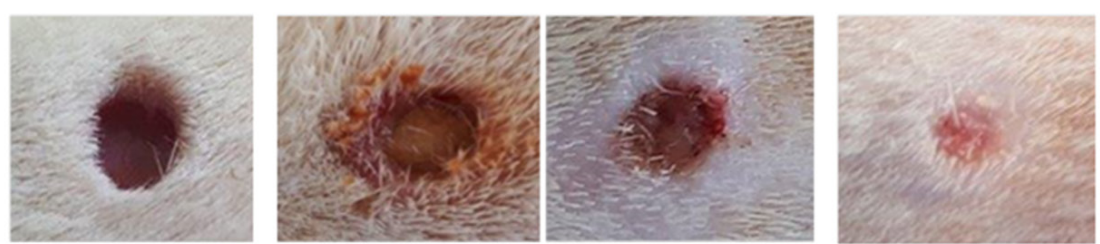

FIGURE 4. Photographs of macroscopic appearance of wounds treated with the formulated creams 


\section{CONCLUSION}

In the present study, various sea cucumber extract-based creams for wound healing applications were formulated with different type of natural oils; olive oil (F1), tea tree oil (F2) and lemongrass oil (F3). All formulations showed good physicochemical properties such as stability to various extreme conditions, compatible with the physiological skin $\mathrm{pH}$ and high spreadability. During the membrane release studies, F3 depicted a higher sea cucumber extract concentration released from the cream formulations, followed by F2 and F1. All formulated creams substantially stimulated wound healing than control group in the animal wound model, which F1 appeared to be statistically significant in accelerating the wound closure compared to F2 and F3. Our data demonstrated that the outcome of Franz cell ex vivo release analysis was not correlated to the performance of the formulated creams in inducing wound healing in in vivo. The findings suggested that the synergistic activity between oil phases and sea cucumber extract have a more profound effect in promoting wound healing compared to the role of the oil as a delivery vehicle of active substance. Further study on the exact constituents of the naturallyderived oils that contribute to the synergy effects with sea cucumber extract would be beneficial to assess its usefulness and mechanism of wound healing activity.

\section{ACKNOWLEDGEMENTS}

The authors acknowledge the financial support from Universiti Kebangsaan Malaysia (UKM) with the grant code GGPI-2016-008. The authors would like to thank the Faculty of Pharmacy, UKM for the research facility support. We would also like to thank Healwell Pharmaceuticals Sdn Bhd for providing the sea-cucumber extract.

\section{REFERENCES}

Aqil, M., Ahad, A., Sultana, Y. \& Ali, A. 2007. Status of terpenes as skin penetration enhancers. Drug Discov. Today 12(23-24): 1061-1067. doi: 10.1016/j.drudis.2007.09.001.

Cai, Y., Yang, W., Yin, R., Zhou, L., Li, Z., Wu, M. \& Zhao, J. 2018. An anticoagulant fucan sulfate with hexasaccharide repeating units from the sea cucumber Holothuria albiventer. Carbohydr. Res. 464: 12-18. doi: 10.1016/j.carres.2018.05.007.

Carson, C.F., Hammer, K.A. \& Riley, T.V. 2006. Melaleuca alternifolia (Tea Tree) oil: A review of antimicrobial and other medicinal properties. Clin. Microbiol. Rev. 19(1): 50-62. doi: 10.1128/CMR.19.1.50-62.2006.

Chen, J., Jiang, Q.D., Chai, Y.P., Zhang, H., Peng, P. \& Yang, X.X. 2016. Natural terpenes as penetration enhancers for transdermal drug delivery. Molecules 21(12): 1709. doi: 10.3390/molecules21121709.
Chikakane, K. \& Takahashi, H. 1995. Measurement of skin $\mathrm{pH}$ and its significance in cutaneous diseases. Clin. Dermatol. 13(4): 299-306.

Donato-Trancoso, A., Monte-Alto-Costa, A. \& Romana-Souza, B. 2016. Olive oil-induced reduction of oxidative damage and inflammation promotes wound healing of pressure ulcers in mice. J. Dermatol. Sci. 83(1): 60-69. doi: 10.1016/j. jdermsci.2016.03.012.

Gouvinhas, I., Machado, N., Sobreira, C., Domínguez-Perles, R., Gomes, S., Rosa, E. \& Barros, A.I. 2017. Critical review on the significance of olive phytochemicals in plant physiology and human health. Molecules 22(11): 1986. doi: 10.3390/ molecules 22111986 .

Herman, A. \& Herman, A.P. 2015. Essential oils and their constituents as skin penetration enhancer for transdermal drug delivery: A review. J. Pharm. Pharmacol. 67(4): 473485. doi: 10.1111/jphp.12334.

Himaya, S.W.A., Ryu, B., Qian, Z.J. \& Kim, S.K. 2010. Sea cucumber, Stichopus japonicus ethyl acetate fraction modulates the lipopolysaccharide induced iNOS and COX2 via MAPK signaling pathway in murine macrophages. Environ. Toxicol. Pharmacol. 30(1): 68-75. doi: 10.1016/j. etap.2010.03.019.

Kwak, M.S., Ahn, H.J. \& Song, K.W. 2015. Rheological investigation of body cream and body lotion in actual application conditions. Korea Aust. Rheol. J. 27(3): 241-251. doi: 10.1007/s13367-015-0024-x.

Lambers, H., Piessens, S., Bloem, A., Pronk, H. \& Finkel, P. 2006. Natural skin surface $\mathrm{pH}$ is on average below 5 , which is beneficial for its resident flora. Int. J. Cosmet. Sci. 28(5): 359-370. doi: 10.1111/j.1467-2494.2006.00344.x.

Mamelona, J., Pelletier, E., Girard-Lalancette, K., Legault, J., Karboune, S. \& Kermasha, S. 2007. Quantification of phenolic contents and antioxidant capacity of Atlantic sea cucumber, Cucumaria frondosa. Food Chemistry 104(3): 1040-1047. doi: https://doi.org/10.1016/j. foodchem.2007.01.016.

Martin, P. \& Nunan, R. 2015. Cellular and molecular mechanisms of repair in acute and chronic wound healing. $B r . J$. Dermatol. 173(2): 370-378. doi: 10.1111/bjd.13954.

Matousek, J.L., Campbell, K.L., Kakoma, I., Solter, P.F. \& Schaeffer, D.J. 2003. Evaluation of the effect of $\mathrm{pH}$ on in vitro growth of Malassezia pachydermatis. Can. J. Vet. Res. No. 67(1): 56-59.

Nanayakkara, G.R., Bartlett, A., Forbes, B., Marriott, C., Whitfield, P.J. \& Brown, M.B. 2005. The effect of unsaturated fatty acids in benzyl alcohol on the percutaneous permeation of three model penetrants. Int. J. Pharm. 301(12): 129-139. doi: 10.1016/j.ijpharm.2005.05.024.

Narishetty, S.T.K. \& Panchagnula, R. 2004. Transdermal delivery of zidovudine: Effect of terpenes and their mechanism of action. J. Control Release 95(3): 367-379. doi: 10.1016/j.jconrel.2003.11.022.

Oh, G.W., Ko, S.C., Lee, D.H., Heo, S.J. \& Jung, W.K. 2017. Biological activities and biomedical potential of sea cucumber (Stichopus japonicus): A review. Fish Aquatic Sci. 20: 1-17. doi: 10.1186/s41240-017-0071-y. 
Omran, N.E. \& Allam, N.G. 2013. Screening of microbial contamination and antimicrobial activity of sea cucumber Holothuria polii. Toxicol. Ind. Health 29(10): 944-954. doi: 10.1177/0748233712448116.

Pessoa, A.F.M., Florim, J.C., Rodrigues, H.G., Andrade-Oliveira, V., Teixeira, S.A., Vitzel, K.F., Curi, R., Saraiva Camara, N.O., Muscará, M.N., Lamers, M.L. \& Santos, M.F.. 2016. Oral administration of antioxidants improves skin wound healing in diabetic mice. Wound Repair Regen. 24(6): 981993. doi: 10.1111/wrr.12486.

Pham, Q.D., Björklund, S., Engblom, J., Topgaard, D. \& Sparr, E. 2016. Chemical penetration enhancers in stratum corneum - Relation between molecular effects and barrier function. J. Control Release 232: 175-187. doi: 10.1016/j. jconrel.2016.04.030.

Rivera, A.E. \& Spencer, J.M. 2007. Clinical aspects of fullthickness wound healing. Clin. Dermatol. 25(1): 39-48. doi: 10.1016/j.clindermatol.2006.10.001.

Süntar, I., Akkol, E.K., Nahar, L. \& Sarker, S.D. 2012. Wound healing and antioxidant properties: Do they coexist in plants? Free Radicals and Antioxidants 2(2): 1-7. doi: https:// doi.org/10.5530/ax.2012.2.2.1.
Takeuchi, H., Mano, Y., Terasaka, S., Sakurai, T., Furuya, A., Urano, H. \& Sugibayashi, K. 2011. Usefulness of rat skin as a substitute for human skin in the in vitro skin permeation study. Exp. Anim. 60(4): 373-384. doi: 10.1538/ expanim.60.373.

Viljoen, J.M., Cowley, A., Du Preez, J., Gerber, M. \& Du Plessis, J. 2015. Penetration enhancing effects of selected natural oils utilized in topical dosage forms. Drug Dev. Ind. Pharm. 41(12): 2045-2054. doi: 10.3109/03639045.2015.1047847.

Zhang, Y., Yang, N., Xu, Y., Wang, Q., Huang, P., Nishinari, K. \& Fang, Y. 2019. Improving the stability of oil body emulsions from diverse plant seeds using sodium alginate. Molecules 24(21): 3856. doi: 10.3390/molecules24213856.

Centre for Drug Delivery Research

Faculty of Pharmacy

Universiti Kebangsaan Malaysia

Jalan Raja Muda Abdul Aziz

50300 Kuala Lumpur, Federal Territory

Malaysia

*Corresponding author; email: fazren.azmi@ukm.edu.my

Received: 17 June 2020

Accepted: 16 August 2020 